\title{
The Worsening Shortage of College-Graduate Workers
}

\author{
John H. Bishop and Shani Carter \\ Cornell University
}

\begin{abstract}
The Bureau of Labor Statistics (BLS) projections of occupational employment growth have consistently underpredicted the growth of skilled occupations. BLS currently projects that professional, technical, and managerial jobs will account for $44.5 \%$ of employment growth between 1988 and 2000, while we project they will account for $70 \%$ of employment growth. Between March 1988 and March 1991 these occupations, in fact, accounted for 87\% of employment growth. The BLS's projections of the supply/demand balance for college graduates have also been off the mark-predicting a surplus for the 1980s when, in fact, a shortage developed, and relative wage ratios for college graduates rose to all-time highs. We project that the supply of college educated workers will grow more slowly during the 1990s and that there will be a continuing escalation of wage premiums for college graduates.
\end{abstract}

Are we heading into an era of strong demand and insufficient supply of college graduate workers? If Workforce 2000 (Johnston \& Packer, 1987) is to be believed, the answer is yes. Others are skeptical, however. Levin and Rumberger (1987) have stated:

In summary, the evidence suggests that new technologies are unlikely to have a profound effect in upgrading the education and skill requirements of jobs, and that most new jobs or job openings will be in occupations that require relatively low skills and education. (p. 344).

Mishel and Teixeira (1991) predict:

The effect of occupational upgrading on job skills is actually projected to slow down in the future to one-third to one-fourth of its rate in the recent past. (p. 1)

Sargent (1988) of the Bureau of Labor Statistics (BLS) also appears to be skeptical, for he predicts:

The number of college graduates entering the labor force over the $1986-2000$ period is projected to continue to exceed the number of openings in jobs requiring 4 or more years of college education by an average of
100,000 annually, or a total of about 1.4 million. (p. 8)

In 1990 the BLS projected the number of graduates entering the labor force over the 1988-2000 period "to exceed the number of job openings in jobs requiring 4 or more years of college by an average of 150,000 annually" (Sargent \& Pfleeger, 1990, p. 8).

The issue under debate here is the skill and education requirements that are implied by a given occupational employment distribution, not the occupational employment distribution that is projected to prevail in the year 2000. Both Workforce 2000 and the statements quoted above are based on manipulations of BLS projections of occupational employment published in September 1987 and November 1989. Until now, participants in this debate have not questioned the BLS projections. In fact, some participants (those who do not work at the BLS) appear to put so much faith in these projections that they use auxiliaries like "will" and "shall" when describing the year 2000 scenario projected by the BLS's computer.

In this article we take a look at these BLS projections and find them wanting. In the 
first section we demonstrate that, in the past, BLS projections have systematically underpredicted the growth of occupations that require the greatest amount of education and training. Next, we examine the latest data on occupational growth rates and conclude that the BLS's recent projections of occupational employment growth out to the year 2000 probably suffer from the same bias. According to a regression analysis of trends in occupational shares, the forecasts of occupational employment demand in the year 2000 based on these regressions imply substantially faster growth of higher level occupations than do the BLS projects.

In the following section of the article, we do our own examination of the supply/demand balance for college graduates by comparing past and projected percentage rates of change in employment in high-skill jobs to actual and projected rates of change in the stock of well educated workers. During the 1980s, employment in professional, technical, managerial, and sales representative occupations grew at nearly the same rate as the stock of workers with one or more years of college. Employers wished to increase the proportion of workers in managerial and sales occupations who had a college education, but a shortage developed and the wage premium for college graduates rose to unprecedented levels. Our projections for the 1990s predict that the labor market for college graduates will get even tighter.

We conclude the article with a discussion of its implications for policy. If the supply of college educated workers cannot be expanded more rapidly than is projected (either through greater immigration of highly educated skilled workers or by increasing the number of Americans attending and graduating from college), wage premiums for college are likely to continue to grow. Shortages are particularly severe in business and technical fields, and this has resulted in graduates of business and engineering programs receiving much higher wages than do graduates who have majored in the humanities, education, and social sciences other than economics. These wage differentials have helped induce a very rapid growth in the numbers of students majoring in business and engineering.
The wage advantage of graduates in engineering and physical science over those in the liberal arts has fallen a little from the peak reached in 1980, but it remains substantially above the premiums that prevailed during the 1960 s.

\section{The Skill Shortage Debate at the Beginning of the 1980s}

The Bureau of Labor Statistics, as well as Levin and Rumberger, have been in the business of forecasting occupational employment growth for a number of years. What does the track record of their forecasts look like?

At the beginning of the 1980s there was a lively debate over the effects of technological change on skill demands and the likely supply-demand balance for college graduates. The Education Commission of the States, for example, argued in 1982 as follows:

Occupational growth throughout the 1980s is projected to expand most rapidly in the higher-skilled, technical occupations. Tomorrow's workers will likely need improved skills in the selection and communication of information. Many of today's skills considered to be of a "higher" level are the potential basic skills of tomorrow (quoted in Levin \& Rumberger 1983, p. 2).

Basing their judgments on BLS projections published in August 1981. Levin and Rumberger (1983) argued to the contrary:

The expansion of the lowest skilled jobs in the American economy will vastly outstrip the growth of high technology ones; and the proliferation of high technology industries and their products is far more likely to reduce the skill requirements of jobs in the U.S. economy than to upgrade them. (p. i)

In February 1984, they said, "future job growth will favor service and clerical jobs that require little or no post-secondary schooling and that pay below-average wages" (Levin \& Rumberger, 1984).

Parallel disagreements existed over whether college graduates were likely to be in surplus or shortage during the 1980s. During the 1970s college graduates had been in excess supply, and many graduates were apparently forced to take jobs in occupations that were not traditionally considered to require a college degree. The ratio of college graduate 
wages to high school graduate wages fell $11 \%$ between 1973 and 1979. The Bureau of Labor Statistics projected that this situation would continue in the 1980s. Testifying before the Senate Committee on Labor and Human Resources, Norwood (1979) stated:

\section{College graduates entering the labor force through the 1980s are likely to face job mar- ket conditions very similar to those faced by graduates during the 1970 s as entrants con- tinued to exceed openings in jobs tradi- tionally sought by graduates. (p. 7)}

In 1982 Sargent predicted that "a surplus of between 2 and 3 million college graduates is expected to enter the labor force during the 1980s" (p. 7).

On the other side of the issue was Richard Freeman, the economist who had been the first to call attention to the surplus of college graduates in the 1970s and the resulting declines of college wage premiums. In his 1976 book, The Overeducated American, he presented an empirical model of the college graduate labor market which predicted continued moderate declines of the college wage differential during the 1970s and an upswing during the 1980s. He reiterated this prediction in 1982 (Freeman \& Hansen, 1983):

The most interesting prediction of the model-that of an increase in [the college] enrollments ratio, as well as in [college] salaries in the mid to late 1980 s - cannot be examined at this time. (p. 98).

The decade is over, so it is now possible to settle these two controversies.

\section{BLS Projections of Occupational Employment Growth in the 1980s}

In August 1981 the BLS projected that professional, technical, and managerial (PT\&M) jobs would increase only slightly more rapidly than total employment during the 1980s. It was estimated that PT\&M jobs would account for $28 \%$ of employment growth between 1978 and 1990 and that operatives, laborers, farm laborers, and service workers (OL\&S) would account for $34 \%$ of employment growth (Carey, 1981). In November 1983, BLS projected that professional, technical, and managerial employment would account for $30.7 \%$ of employment growth through 1995 from the 1982 base and for $37 \%$ of the growth from the 1979 base. BLS projected that OL\&S would account for $31.5 \%$ of growth from the 1982 base, and $27.9 \%$ of growth from the 1979 base (Silvestri, Lucasiewicz, \& Einstein, 1983). What were the actual patterns of the job growth between 1978 and 1989? Professional, technical, and managerial jobs, which were $24.9 \%$ of the nation's jobs in 1978 , accounted for $52 \%$ of the job growth between 1978 and 1989. High-level sales representative and manager jobs accounted for another $10 \%-11 \%$ of job growth. Operative, laborer, farm laborer, and service jobs, which were $37 \%$ of jobs in 1978, accounted for only 9\% of the job growth between 1978 and 1989 (Klein, 1984; U.S. Bureau of Labor Statistics, 1990 [Table 20].

Table 1 presents a detailed comparison of BLS's 1981 projections of occupational employment growth between 1978 and 1990, with actual growth rates between 1978 and 1989. Because the comparison employs the 1980 census occupational categories, adjustments were made to the BLS projections to account for the occupations that were switched from one major occupational group to another. ${ }^{1}$ The first column of the table presents the actual percentage growth of occupational employment between 1978 and 1989. The second column of the table presents the low-trend projected percentage growth for 1978 to 1990 that was published by BLS in 1981. The low-trend is used for comparison because actual employment levels in 1989 were very close to BLS's low-trend projection for 1990. The third column presents the difference between the actual and projected percentage increases for each occupation. The fourth column presents the difference between actual and projected numbers of people in the occupation in 1989. The largest error was in BLS's projection of the growth of managerial occupations. It underestimated the growth of managerial employment by $36.4 \%$ of the 1978 level of managerial employment, or by 3.4 , million jobs. The Occupational Employment Survey (OES) yields an almost identical estimate (53\% rather than $56.7 \%$ ) of the growth of managerial employment and of the projec- 
TABLE 1

Comparison of Actual and Projected Growth of Major Occupational Groups in the 1980s

\begin{tabular}{lcccrr}
\hline & $\begin{array}{c}\text { Act. GR } \\
1978-1989 \\
(\%)\end{array}$ & $\begin{array}{c}\text { BLS proj. } \\
\text { GR 1978- } \\
1990(\%)\end{array}$ & $\begin{array}{c}\text { Act. minus } \\
\text { proj. as \% } \\
\text { of base }\end{array}$ & $\begin{array}{c}\text { Act. minus } \\
\text { proj. } \\
(1,000 s)\end{array}$ & $\begin{array}{r}\% \text { share } \\
\text { of employ. } \\
\text { increase }^{\mathrm{a}}\end{array}$ \\
\hline Major occupation & 22.1 & 22.5 & -.4 & & 100 \\
Total & 56.7 & 20.3 & 36.4 & 3,401 & 25 \\
Exec., admin., pub. admin. & 42.3 & 25.3 & 17.0 & 1,858 & 22 \\
Professional & 45.8 & 41.8 & 4.0 & 100 & 5 \\
Technical & 36.7 & 26.3 & 10.4 & 1,070 & 18 \\
Sales occupations & 18.4 & 23.6 & -5.2 & -809 & 13 \\
Administrative support & 35.9 & 32.3 & 3.6 & 52 & 2 \\
Protective service & -26.1 & -15.3 & -10.8 & -127 & -1 \\
Private household & 24.3 & 36.0 & -11.7 & $-1,198$ & 12 \\
Other services & 13.9 & 23.9 & -10.0 & $-1,214$ & 8 \\
Precision production, craft & -10.0 & 14.1 & -24.1 & $-2,209$ & -4 \\
Machine operators & 7.9 & 20.4 & -12.5 & -566 & 2 \\
Transportation operatives & -3.9 & 16.9 & -20.8 & $-1,057$ & -1 \\
Laborers & -7.9 & -13.1 & 5.2 & 193 & -1 \\
Farming, forestry, fishing & &
\end{tabular}

Note. Exec. = executive; admin. = administrative; pub. = public; GR = growth rate; Act. = actual; Proj. = projected; BLS = Bureau of Labor Statistics; Employ. = employment. Sources: Data on the actual levels of employment are from the U.S. Bureau of Labor Statistics $(1984,1990$.) Information on the changes in occupational definitions in 1982 is from Green, Dinh, Pirebe, and Tucker (1983). Projected low-trend percentage growth is from Carey (1981). The comparison employs the 1980 census occupational categories; thus, adjustments were made to BLS projections to account for the occupations that were switched from one major occupational group to another.

${ }^{\text {aOOf }} 21,294,000$.

tions error. ${ }^{2}$ The error in projecting managerial employment was roughly equal to the total number of bachelor's and master's degrees awarded in business, marketing, and accounting between 1978 and 1989. The growth of professional employment was underestimated by 1.86 million jobs (17\% of the 1978 level of professional employment) when current population survey (CPS) data are used to measure growth of professional jobs. If OES data are used, there is no forecast error for professional and technical jobs combined.

Operative employment was projected to grow by $14 \%$; it fell instead by $10 \%$, resulting in an overprediction of 2.2 million jobs. In OES data the drop is even more precipitous. Employment in other services was projected to grow by $36 \%$; it grew by $24 \%$, resulting in an overprediction of 1.2 million jobs. Rates of growth for all low-skill jobs combinedoperatives, laborers, farm laborers, and service workers-are identical in OES and CPS data; thus, our conclusion that the 1981 pro- jections significantly overpredicted the growth of low-skill jobs is independent of the source of data on the growth of occupational employment. The growth of other professional employment was underestimated by 1.86 million jobs (17\% of the 1978 level of professional employment). ${ }^{3}$

Just as one sided in its testimony on the issue is the recent behavior of occupational wage differentials. The wage premium that employers must pay for skilled workers tells us a lot about the demand-supply situation for skills. If demand for more skilled workers shifts out more rapidly than the supply, the relative wage of skilled workers will rise. And, indeed, skilled workers have been getting higher real wages: the increase in real weekly earnings between 1983 and 1989 was $16.1 \%$ for technicians, $12 \%$ for professional workers, $1.5 \%$ for managers, $6.4 \%$ for sales representatives selling commodities outside of retailing, and $1.5 \%$ for sales representatives in finance and business services. If the demand for unskilled workers shifts out less 
rapidly than their supply, they will tend to suffer declines in relative wages. Between 1983 and 1989, a period of recovery from a deep recession, real weekly earnings of operators, fabricators, and laborers declined $5.3 \%$, and the real weekly earnings of service workers declined $1.3 \%$ (U.S. Bureau of Labor Statistics, 1984 [Table 56], 1990 [Table 65]. Real hourly wages of nonsupervisory employees fell $8.1 \%$ in retailing and $4.4 \%$ in manufacturing.

\section{An Evaluation of BLS Occupational Projections for the Year 2000}

The projections of occupational skill demands for the year 2000 used by Workforce 2000 , by Levin and Rumberger, and by Sargent and other BLS authors are based on the same flawed methodology that failed to predict the strong growth of high-skill occupations during the $1980 \mathrm{~s}$. It is, therefore, reasonable to hypothesize that the latest projections will understate upskilling trends of the 1990s. If so, the forecast shortage of skilled and educated workers is probably even more serious than Workforce 2000 projects.

One can see this unfolding in Table 2. The actual growth shares calculated for 1986 through 1991 presented in columns 1 and 2 may be compared with BLS's forecast growth shares for 1986 to 2000 in column 3 and for 1988 to 2000 in column $4 .{ }^{4}$ BLS forecasts that managerial, professional, and technical jobs will account for $41.4 \%$ and $44.5 \%$, respectively, of job growth to the year $2000 .^{5}$ Actual employment growth in the latter half of the 1980s has turned out to be more heavily weighted toward high-skill jobs than projected. The three occupations listed above accounted for $52 \%$ of job growth between 1986 and 1988 and $87.5 \%$ of growth between March 1988 and March 1991. In 1987 and 1989 , BLS projected that operative, laborer, farm laborer, and service jobs would account for $23.3 \%$ and $20.5 \%$, respectively, of job growth to the year 2000 . These low-skill jobs did account for $25.1 \%$ of job growth between 1986 and 1988 but only $11.5 \%$ of job growth between 1988 and 1991.

Still another way to evaluate BLS projections is to compare their predictions with forecasts based on a regression analysis of changes in occupational employment shares during the 1972-1989 period. The source of the yearly data on occupational employment is the Current Population Survey. Consequently, the dependent variable is the share of workers who describe themselves as being in a given occupation, not the share of jobs that employers describe as being in a particular occupation. The advantage of CPS data is that there is no double counting of workers with more than one job, and there is no danger of missing jobs being generated at new companies as there is with data derived from establishment surveys. For supply/demand comparisons, CPS data have the further advantage of also being the source of data on educational attainment. This means that underenumeration of undocumented workers and homeless individuals has little effect on estimates of the balance between supply and demand because these individuals are excluded from both sides of the equation. The disadvantage of CPS data is the possibility that self-reports of occupation are less accurate than data collected from employers (see Appendix A for a detailed comparison of CPS and OES data on the occupational composition of the workforce).

Changes in occupational employment shares were assumed to follow a logistic growth path. The logistic function was assumed to have a ceiling of $20 \%$. The ceiling was set at the rather low $20 \%$ level because this fit the data slightly better than a ceiling set at $25 \%$ and because it would build in a slowdown in the rate of growth for three large, fast-growing occupations-managers, professionals, and sales workers. The variables that had significant effects on occupational shares during the 1972 to 1989 period were as follows: a simple trend, the unemployment rate, the merchandise trade deficit as a proportion of the gross national product (GNP), and the ratio of personal computers used in business to total employment. The personal computer variable captures the accelerated introduction of computer technology during the 1980 s, as well as the direct effects of microcomputers. Full details on model specification, the results obtained, 
TABLE 2

Occupational Shares of Employment Growth (in \%)

\begin{tabular}{|c|c|c|c|c|c|}
\hline \multirow[b]{3}{*}{ Occupation } & & & \multicolumn{3}{|c|}{ Projected } \\
\hline & \multicolumn{2}{|c|}{ Actual } & & BLS & $\begin{array}{c}\text { Bishop \& } \\
\text { Carter }\end{array}$ \\
\hline & $1986-1988^{a}$ & $1988-1991^{b}$ & $1986-2000^{c}$ & $1988-2000^{d}$ & $1988-2000$ \\
\hline \multicolumn{6}{|l|}{ Major } \\
\hline Managerial & 29.3 & 34.8 & 17.3 & 17.8 & 34.8 \\
\hline Professional & 19.8 & 39.7 & 17.9 & 20.4 & 26.7 \\
\hline Technical & 2.9 & 13.0 & 6.1 & 6.3 & 8.2 \\
\hline Sales rep. \& manager & 6.8 & -2.3 & 10.3 & 10.0 & 9.9 \\
\hline Sales clerk & 2.5 & 12.2 & 8.4 & 5.9 & 7.8 \\
\hline Clerical & 9.7 & 5.2 & 9.6 & 12.3 & 13.5 \\
\hline Craft & 4.8 & -11.5 & 7.7 & 7.7 & -1.4 \\
\hline Factory oper. & 3.8 & -15.9 & -1.5 & -2.7 & -9.0 \\
\hline Transportation oper. & 5.0 & 4.6 & 2.3 & 3.2 & -0.1 \\
\hline Laborer & 3.4 & -10.4 & 1.3 & 0.6 & -2.2 \\
\hline Private household & -1.3 & -3.4 & -0.1 & -0.2 & -1.3 \\
\hline Protective service & 2.9 & 6.4 & 2.7 & 2.5 & 3.8 \\
\hline Other service & 10.5 & 28.8 & 18.7 & 17.2 & 11.7 \\
\hline Farm manager & -0.9 & -2.7 & -1.4 & -1.3 & -1.4 \\
\hline Farm laborer & 0.8 & 1.4 & 0.6 & 0.4 & -1.1 \\
\hline Total & 100.0 & 100.0 & 100.0 & 100.0 & 100.0 \\
\hline $\begin{array}{l}\text { Total employment } \\
\text { growth (in } 1,000 \mathrm{~s} \text { ) }\end{array}$ & 5,371 & 2,772 & 20,929 & 17,590 & 17,590 \\
\hline $\begin{array}{l}\text { High-skill manager } \\
\text { prof. \& tech. }\end{array}$ & 52.0 & 87.5 & 41.4 & 44.5 & 69.8 \\
\hline $\begin{array}{l}\text { Manager, prof., tech., } \\
\text { sales rep., \& sales } \\
\text { manager }\end{array}$ & 58.8 & 85.2 & 51.7 & 54.4 & 79.7 \\
\hline $\begin{array}{l}\text { Low-skill oper., lab., } \\
\text { farm lab., \& service }\end{array}$ & 25.1 & 11.5 & 23.3 & 20.5 & 1.9 \\
\hline $\begin{array}{l}\text { Oper., lab., farm lab., } \\
\text { service, \& sales } \\
\text { clerk }\end{array}$ & 27.6 & 23.7 & 32.3 & 26.4 & 9.7 \\
\hline
\end{tabular}

Note. BLS = Bureau of Labor Statistics; rep. = representative; oper. = operative; prof. = professional; tech. = technician; lab. = laborer.

aSources: U.S. Bureau of Labor Statistics (1987, January, Table 20, p. 177; 1989a, January, Table 20, p. 181).

bSources: U.S. Bureau of Labor Statistics (1988a, April, Table A-22, p. 30; 1991, April, Table A-22, p. 29).

'Source: Silvestri and Lucasiewics (1987).

${ }^{\mathrm{d} S o u r c e: ~ S i l v e s t r i ~ a n d ~ L u c a s i e w i c s ~(1989) . ~}$

and the method of calculating the projections are given in Appendix B.

In order to predict occupational shares for the year 2000, we must first project unemployment, the trade deficit, and the ratio of microcomputers used by business to employment in the year 2000 . Because the foreign debt of the United States cannot grow at current rates indefinitely and because the growing debt must eventually be serviced by exporting more goods than are imported, our projections assume that merchandise trade will be in balance in the year 2000 . It was further assumed that unemployment will be $5.5 \%$ and the ratio of microcomputers to employment will increase from its 1989 level of $21 \%$ to $45 \%$ in $2000 .^{6}$

The results of these projections are summarized in column 5 of Table 2 . We project that growth of managerial, professional, and technical jobs will remain strong, and we expect these occupations to account for nearly 
$70 \%$ of growth of occupational demand between 1988 and 2000 . BLS, by contrast, projects that the growth of managerial and professional jobs will slow and that these three occupations will account for only $44.5 \%$ of job growth. We are projecting absolute declines of employment for craft workers, factory operatives, transport operatives, laborers, and private household workers. Protective service employees are projected to grow rapidly, but remaining service occupations are projected to grow at roughly the same rate as total employment. We project that low-skill jobs-operatives, laborers (farm and factory), service workers, and sales clerks - will account for only about $10 \%$ of job growth to the year 2000 . BLS, by contrast, projects that $26 \%$ of job growth will be in these low-skill occupations. It is also useful to contrast our projections with the actual shares of job growth for 1986 to 1991 that are reported in columns 1 and 2 of the table. Our regressions do not project that differentials in growth rates between highskill and low-skill jobs will be larger in the 1990 s than in the 1980 s. Nevertheless, we project that the high-skill share of job growth between 1990 and 2000 will be substantially higher than it was during the 1980 s. The reason for this is the expected slowdown in the growth of the total labor force during the 1990 s because of the baby bust of the early 1970s. Because all occupations are expected to grow more slowly in the 1990 s than in the 1980 s, the occupations that are a rapidly declining share of all jobs are projected to experience absolute declines in employment. Growth of high-skill occupations is projected to slow down as well, but their share of total job growth is projected to increase because the denominator, total job growth, has been reduced by an even larger percentage.

\section{The Supply-Demand Balance for College-Educated Workers}

\section{BLS Projections of Supply-Demand Balance for College-Graduate Workers}

What about the Bureau of Labor Statistics' 1980 forecasts of a continuing surplus of college graduates? It is extremely difficult to make accurate forecasts of rates of change of the supply-demand balance for college-edu- cated labor-much more difficult than projecting occupational employment alone. Small errors in forecasting rates of change of demand or supply can translate into big errors in projecting the gap between supply and demand.

Despite the difficulties, BLS has been publishing biannual projections of the supplydemand balance for the past two decades. The starting point of its projections is its forecasts of occupational employment growth. It then projects changes in the proportion of particular occupations that "require a college degree," the number of bachelor's degrees to be awarded per year, and the annual rates of flow into and out of jobs by workers with a college degree. Comparisons are then made between the projected number of job openings "requiring a college degree" and the projected flow of college graduates seeking work (Sargent \& Pfleeger, 1990). The record of these projections is presented in column 3 of Table 3.

Quite clearly, the BLS effort to project the supply-demand balance for college graduates has been a failure. Such a judgment is possible because changes in the ratio of young college graduate wages to young high school graduate wages over the projection period provide an ex post criterion for evaluating the accuracy of the projections of supply-demand balance. At the beginning of the 1970s, BLS projected a rough balance of supply and demand during the subsequent decade. If the projection had been correct, the relative wage of college graduates should have been stable during the period as indicated by column 4 of the table. In fact, however, the supply of college graduates grew more rapidly than demand, and, as a result, the college/high school wage ratio for workers with 1-5 years of postschool work of experience fell 6.7-7.6 percentage points by 1980 (see column 5) (Katz \& Murphy, in press). At the end of the 1970s, BLS projected very large surpluses of college graduates during the subsequent decade. According to their projection, the surplus of college graduates was going to grow at a rate equal to $30 \%$ of the annual flow of bachelor's degrees awarded. If the projections had been correct, the surplus should have caused the relative 
TABLE 3

BLS Projections of the Supply-Demand for College Graduates and Subsequent Changes in the College Wage Premium

\begin{tabular}{|c|c|c|c|c|}
\hline \multirow{2}{*}{$\begin{array}{l}\text { When } \\
\text { published }\end{array}$} & \multirow{2}{*}{$\begin{array}{l}\text { Projection } \\
\text { period }\end{array}$} & \multirow{2}{*}{$\begin{array}{l}\text { Proj. ave. } \\
\text { annual surplus } \\
\text { (in } 1,000 \text { s) }\end{array}$} & \multicolumn{2}{|c|}{$\begin{array}{c}\text { Change in CG/HS } \\
\text { wage ratio }(\%)\end{array}$} \\
\hline & & & Implied & Actual \\
\hline 1970 & $1968-1980$ & 8 & Stability & -6.7 \\
\hline 1972 & 1970-1980 & 20 & Stability & -7.6 \\
\hline 1974 & $1972-1985$ & 62 & Stable/decline & +14.2 \\
\hline 1976 & 1974-1985 & 86 & Stable/decline & +18.9 \\
\hline 1978 & 1976-1985 & 300 & Big decline & +23.2 \\
\hline 1980 & 1978-1990 & 275 & Big decline & +26.5 \\
\hline 1982 & 1980-1990 & 300 & Big decline & +23.6 \\
\hline 1984 & $1982-1995$ & 300 & Big decline & \\
\hline 1986 & 1984-1995 & 200 & Decline & \\
\hline 1988 & $1986-2000$ & 100 & Small decline & \\
\hline 1990 & 1988-2000 & 150 & Decline & \\
\hline
\end{tabular}

Note . Proj. = projected; ave. $=$ average CG = college graduate; $\mathrm{HS}=$ high school graduate. The record of past U.S. Bureau of Labor Statistics forecasts of the supply-demand balance is from Sargent and Pfleeger (1990). The data on subsequent changes in the ratio of college and high school wages for workers with 1-5 years of experience are from Katz and Murphy (in press).

wage of college graduates to fall during the subsequent decade. In fact, however, increased demand for college graduates substantially outstripped increased supply, and the college/high school wage ratio for those with 1-5 years of experience rose by $23-26$ percentage points to all-time highs. Thus, the projections were much worse than uncorrelated with the truth-they were negatively correlated with the truth.

The problems are much deeper than simple errors in forecasting future occupational employment levels. The description of the present and recent past is wrong as well. It is stated, for example, that $27 \%(6,659,000)$ of college graduates were "underemployed" in 1988 and that "underemployment" increased by 1,655,000 between 1983 and 1988 . Clearly, a measure of underemployment for a group that increases simultaneously with the group's relative wage is seriously flawed. One of the problems with the approach is the lack of symmetry in the handling of possible mismatches between educational qualifications and occupation. Workers whose education appears to leave them underqualified to perform their job are not characterized as "undereducated." By ruling out the possibility of undereducation, the conceptual framework forces a conclusion that there are too many college graduates.

The task that BLS has set for itself-measuring the level and forecasting changes in the absolute number of jobs which "require a college degree"-is just about impossible. The classification of occupations into a "requires a college degree" category is inherently arbitrary and idiosyncratic to the analyst; yet the validity of the whole effort to measure underemployment depends on this classification being done correctly in every detail not only for the present but also for ten years in the future. This is impossible for four reasons. First, the occupational coding system used by the CPS and the census is not reliable and comprehensive enough to allow accurate measurement of a concept like underemployment. Many of the apparent mismatches between occupation and education are the result of errors in reporting occupation. Census Bureau studies have found that between $18.3 \%$ and $27.3 \%$ of the individual recorded as professionals, technicians, or managers in one interview are recorded in an entirely different major occupational category in a subsequent interview 4 to 7 months later. 
Second, there are also substantial errors in measuring educational attainment. Between $5.5 \%$ and $9 \%$ of respondents who are recorded to have more than 16 years of schooling in one interview are recorded as having fewer than 16 years of schooling in a later interview (U.S. Bureau of the Census, 1972). Still another problem arises from the fact that about $11 \%$ of those who tell census interviewers that they have completed 16 years of schooling also report that they do not have a bachelor's or higher degree (Adkins, 1975; U.S. Bureau of the Census, 1987).

The third problem is that for most occupations, the question "Does it require a college degree?" does not have a yes or no answer. It's a matter of degree. Some employers structure their management jobs in ways that make the skills normally developed in college absolutely essential; with other employers the skills are very helpful, and with still others the skills are of little advantage. The magnitude of the college graduate productivity advantage also depends on the quality of the alternative labor supply. If the competence of those who ended their schooling with high school deteriorates (as it did during the 1970s), the demand for college graduates will increase. The correct answer to the question of whether a college degree is required is, "It depends." It depends on circumstances that analysts and researchers have little knowledge of and no ability to forecast a decade ahead.

The fourth problem is the great heterogeneity of the college graduate category. A psychologist recently asked a community college student who wants to become a teacher, "How many weeks in a year?" She replied, "Hmmm . . . there are 365 days in a year. I don't know! Oh, I'll just double it . . . 730." This student is no doubt an extreme case, but not as extreme as one would like to think. More than $40 \%$ of young adults with associate's and/or bachelor's degrees cannot calculate change from a menu. Seventeen percent of young college graduates read at a level below the typical 11th grader (Kirsch \& Jungeblut, 1986). How can someone with an 11th-grade reading level be considered underemployed in a secretarial, a carpentry, or retail sales job? We conclude that the BLS method of evaluating the balance between supply and demand of college graduates is a blind alley.

If something useful is to be said about the balance between supply and demand, one must put both price and quantity data to work and give up on the idea of measuring how many people are "underemployed."

\section{A Framework for Interpreting Data on the Supply-Demand Balance}

The approach employed in this article is simply to compare percentage changes in supply and demand over time and to interpret these changes in the light of contemporaneous shifts in the wage premium for college. ${ }^{7}$ Changes in the employment of college graduates can be decomposed into two components: (a) shifts that can be explained by changes in the occupational composition of employment and (b) changes in college graduate share of individual occupations. The growth of the engineering profession from $0.13 \%$ of the workforce in 1900 to $1.6 \%$ of the workforce in 1988 is an example of the first source of change. When one projects future occupational employment, one is effectively also projecting this source of change in the demand for college graduates. Historical rates of growth of occupational demand for college graduates are given in the first two rows of Table 4. The second row of the table contains rate of change data for an index of occupational demand for college graduates that was calculated by multiplying employment in each major occupational group in year $t$ by the 1988 proportion of workers in that occupation group who had a college education and then summing across occupational groups. $^{8}$

The third and fourth rows of Table 4 present data on annual rates of change for the supply of college-educated workers. Rates of change for the difference between ex post supply and ex post occupational demand are given in the fifth and sixth rows of the table. The normal state of affairs is for college graduate supply to increase more rapidly than an index driven by shifts in occupational employment shares and for the difference to be made up by increases in skill and educational requirement of specific jobs. 


\begin{tabular}{|c|c|c|c|c|c|c|}
\hline \multirow[b]{3}{*}{ Supply-demand indicators } & \multirow{2}{*}{\multicolumn{4}{|c|}{ Historical growth rate }} & \multirow{2}{*}{\multicolumn{2}{|c|}{$\begin{array}{c}\text { Projected } \\
1988-2000 \\
\text { Bishop } \\
\&\end{array}$}} \\
\hline & & & & & & \\
\hline & $1950-1960$ & $1960-1970^{\mathrm{a}}$ & $1972-1980^{\mathrm{a}}$ & 1980-1988 & Carter & BLS \\
\hline \multicolumn{7}{|l|}{ Demand indicators } \\
\hline $\begin{array}{l}\text { Prof., tech., man., \& sales } \\
\text { rep. }\end{array}$ & 2.69 & 3.00 & 3.92 & 3.45 & 2.49 & 1.7 \\
\hline Occupational demand for $\mathrm{CG}^{\mathrm{d}}$ & 2.29 & 2.93 & 3.43 & 2.89 & 2.14 & 1.6 \\
\hline \multicolumn{7}{|l|}{ Supply } \\
\hline $\mathrm{CG}$ in labor force $(16+\mathrm{yr})$ & 4.96 & 4.34 & 6.22 & $3.76^{\mathrm{f}}$ & 2.50 & 2.5 \\
\hline $\mathrm{CE}$ in labor force $(13+\mathrm{yr})$ & 4.30 & 4.62 & 6.11 & 3.63 & $2.1 / 2.5$ & $2.1 / 2.5$ \\
\hline \multicolumn{7}{|l|}{ Supply minus demand } \\
\hline $\begin{array}{l}\text { CG/prof., tech., man., sales } \\
\text { rep. }\end{array}$ & 2.27 & 1.34 & 2.30 & 0.31 & 0.01 & 0.8 \\
\hline CG/CG occupational demand & 2.67 & 1.41 & 2.79 & 0.87 & 0.36 & 0.9 \\
\hline \multicolumn{7}{|l|}{ College/HS wage ratio } \\
\hline All experience levels & - & $1.1^{\mathrm{b}}$ & $-1.4^{b}$ & $1.5^{\mathrm{b}}$ & - & - \\
\hline $1-5$ yr. experience & $1.2^{\mathrm{c}}$ & $0.5^{\mathrm{c}}$ & $-0.9^{b}$ & $2.8^{\mathrm{b}}$ & - & - \\
\hline \multicolumn{7}{|l|}{$\begin{array}{l}\text { Relative college supply/relative } \\
\text { occupational demand }\end{array}$} \\
\hline $\begin{array}{l}\text { CG occ. dem } \div \text { HS occ. } \\
\text { dem. }{ }^{\text {e }}\end{array}$ & 0.66 & 1.58 & 1.54 & 1.52 & 1.46 & 0.61 \\
\hline CG supply $\div$ HS supply & 3.06 & 3.53 & 4.88 & 3.51 & $2.7 / 3.1$ & $2.7 / 3.1$ \\
\hline $\begin{array}{l}\text { [CG supply } \div \text { HS supply]/ } \\
{[\text { CG occ. dem. } \div \text { HS occ. }} \\
\text { dem.] }\end{array}$ & 2.40 & 1.95 & 3.34 & 2.00 & $1.24 / 1.64$ & $2.1 / 2.5$ \\
\hline
\end{tabular}

Note. BLS = Bureau of Labor Statistics; Prof. = professional; tech. = technical; man. = managerial; rep. = representative; $\mathrm{CG}=$ college graduate; $\mathrm{CE}=$ college educated; $\mathrm{LF}=$ labor force; $\mathrm{HS}=$ high school; occ. $=$ occupation; dem. = demand. Sources: Occupational employment data are from U.S. Bureau of the Census (1975, D184, D185, \& D359-D370; 1990) and from Klein (1984). Data on the education levels of the labor force are from the U.S. Bureau of Labor Statistics (1983, Table 65) and from the 1950 census, Special Report on Occupation, Table 11. Dashes mean that there are no data or that no projection was made.

${ }^{a}$ Data sources are not comparable before and after 1972 because of changes in occupational coding and because prior to 1972, data on the educational levels of the workforce are for individuals above age 18 rather than for those over 16 as in the period after 1972. Rates of change are calculated for periods for which consistently defined data are available. ${ }^{b}$ Annual rates of change in the college/high school wage ratio are for 1963-1971, 1971-1979, and 1979-1987 (Katz \& Murphy, in press).

${ }^{c}$ Annual rates of change for the ratio of yearly earnings of 25-34-year-old White male college graduates to 20-29-year-old White male high school graduates (Marenbach, 1973, pp. 89-90, and 1970 census).

${ }^{\mathrm{d}}$ Occupational demand for college graduates index was calculated by multiplying the proportion of the occupation that had 16 or more years of schooling in 1988 by the actual or projected number of employees in each occupation and summing across occupations.

${ }^{\text {e}}$ Relative college graduate occupational demand was calculated by dividing the occupational demand index for college graduates by an occupational demand index for workers with 12 or fewer years of schooling.

${ }^{\text {fThe }} 4.18 \%$ per year growth of workers reporting college degree to Current Population Survey interviewers has been lowered to $3.76 \%$ per year because overreporting of educational attainment went up substantially during the period.

Engineers work at a knowledge frontier that has been shifting out at an extraordinary pace during the 20th century. Consequently, the skills and training required to perform satisfactorily in this occupations have in- creased. At the beginning of the century, most engineers did not have a bachelor's degree; now a bachelor's degree is required of just about all new entrants, and $20 \%$ of engineers have a master's degree. This demand- 
driven escalation of the educational requirements for being an engineer illustrates the primary reason why college graduate shares of many occupations have increased over time.

This is not, however, the only reason why the share of college graduates in an occupation might increase. During a period when college graduates are in abundant supply, some college graduates may find themselves forced into lower paying occupation which are thought not to require the skills developed in college. The signal that this is happening is declining wage premiums for recent college graduates. If, on the other hand, wage premiums for college graduates and professional occupations are stable or growing at the same time as the share of college graduates in specific occupations is rising, it is reasonable to infer that an outward shift of demand within occupations, not an increase in supply, caused the increase. Rows 7 and 8 of the table provide the data on annual rates of change in the college/high school wage ratio that are essential for interpreting changes in the supply minus occupational demand index reported in rows 5 and 6.

\section{Interpreting the Past}

During the 1960s the relative wage of college graduates rose, even though managerial, professional, technical, and sales representative (MPT\&SR) jobs grew $1.4 \%$ per year more slowly than the number of college graduates in the labor force. Holding occupation constant, this means that there was an exogenous outward shift in demand for college graduates of substantially more than $1.4 \%$ per year during this period. Despite the rise in their relative cost, firms tended to expect new hires to have more schooling than had been expected in previous decades.

The leading edge of the baby boom generation graduated from college in 1970 . The Vietnam war induced a large share of this generation to attend college, and the result was that the number of college graduate workers grew at a $6.22 \%$ annual rate during the 1970 s. The number of workers with 12 or fewer years of schooling grew as well; thus, the ratio of college graduate supply to noncollege supply grew at a rate of $4.88 \%$ per year (see row 10). The number of college graduate workers grew $2.8 \%$ (see row 6) more rapidly than did the college graduate demand index, and relative supply of college graduates grew by $3.34 \%$ (see row 11) more rapidly than relative occupational demand. ${ }^{9}$ Exogenous demand-driven increases in the college graduate shares of particular occupations were not sufficient to make up this gap. A surplus of college graduates developed, wage premiums for college and professional occupations fell, and some graduates were forced into lower level occupations.

During the 1980 s, the number of college graduates in the labor force grew $2.46 \%$ per year more slowly than in the 1970 s. ${ }^{10}$ Growth rates of relative college graduate supply were $1.37 \%$ per year below their level during the 1970s (see row 10) while relative occupational demand for college graduates continued to expand at the rates that prevailed during the 1970s. This meant that college graduate supply was growing only $0.3 \%$ $0.9 \%$ faster than the occupational composition demand indexes. Exogenous increases in demand for college graduates within occupations must have been quite strong, for the wage premium for recent college graduates increased $2.8 \%$ per year between 1979 and 1987 , and the premium for all graduates rose $1.5 \%$ per year. The first eight years of the 1980 s were clearly a period of a growing shortage of college graduates.

\section{Projecting the Future}

We project that percentage growth rates of the supply of college graduates will be substantially smaller during the 12 -year period beginning in 1988 than in the previous decade. Our forecast of the average annual number of BAs awarded is $1,001,000$. This is $1.3 \%$ greater than the latest Department of Education projection for this period. This forecast implies that annual percentage rates of growth in the supply of college graduates will be 1.26 percentage points lower than in the 1980s. ${ }^{11}$ This precipitous decline in the growth of college graduate supply is caused by three phenomena: falling achievement levels and high noncompletion rates in American high schools, the projected decline in the size of the 20-30-year-old age cohort which 
accounts for most students receiving BAs, and the growing number of college-educated workers reaching retirement age during the 1990s.

The growth of demand is also projected to slow, but only by $0.75 \%$ per year. In other words, the shortage of college graduates that prevailed in the 1980s will definitely not end and will almost certainly get worse. This forecast of a worsening shortage of college graduates does not depend on selecting a particular forecasting model or a particular scenario regarding the trade deficit or the spread of microcomputers.

Other ways of measuring the gap between projected supply and demand for college graduates yield similar conclusions. In rows 9-11 of Table 4, we present estimates of growth rates of the relative college graduate supply and relative occupational demand for college graduates. The projected slowdown in the growth of relative occupational demand is only $0.05 \%$ per year, considerably smaller than the $0.36 \%-0.76 \%$ projected decline in the growth of the relative supply of college graduates.

The BLS projections imply a major reduction in the growth of occupational demand for college graduates relative to those with 12 or fewer years of schooling to levels not seen since the 1950s. If BLS projections are correct and within-occupation demand for college graduates continues to escalate at the rates that prevailed in the 1980 s and the $1950 \mathrm{~s}$, the college graduate labor market will remain as tight as it was in 1988, and college wage premiums will probably either continue to rise slowly or stabilize at current levels. The BLS projection of slowly growing relative occupational demand $(0.61 \%$ over year $)$ and modestly growing relative supply $(2.7 \%-3.1 \%$ per year) is very similar to the pattern that prevailed in the 1950 s, a period of slowly rising relative wages for college graduates.

We project that the supply of college graduates will, for the first time this century, grow at almost the same rate as demand created by shifts in the occupational composition of employment. During the 1990 s a rise in the educational qualifications required by one group of employers will force other employers to lower the educational qualifications that they expect of new hires. We predict that a bidding war will break out and thus further widen the gap between the wages of professional and managerial workers and the wages of nonsupervisory employees. ${ }^{12}$ Early evidence does not contradict this prediction. Real wages of nonsupervisory workers fell $3.3 \%$ between the first quarter of 1989 and the first quarter of 1991 while the median earnings of managers rose $1.2 \%$ percent, and the median earnings of professionals fell only $1.5 \%$ (U.S. Bureau of Labor Statistics, [Table A-75], 1989b, 1991 [Table A-75].

\section{The Growing Demand for Graduates}

\section{Trained in Business and Technical Fields}

The shortage appears to be particularly acute for college graduates in business, technical, and scientific fields. Evidence of this shortage is provided by the very large salary premiums commanded by graduates who have majored in physical science, engineering, and business. the first four columns of Table 5 present data from the College Placement Council on how field of study affected the starting salaries received by college graduates whose placement outcomes were reported to the school's placement office for 1963, 1969-1970, 1979-1980, and 1989 (College Placement Council, 1985, 1989). The differences across field are sometimes as large as the wage gains accruing to those obtaining higher level degrees. Engineers currently receive $38 \%-53 \%$ higher starting salaries than do humanities majors, and computer scientists receive $34 \%$ higher starting salaries than do majors in sociology, psychology, and government. Starting salaries for MBAs with less than a year's work experience prior to beginning their program are $58 \%$ higher than the starting salaries of college graduates who have majored in the liberal arts. Data on the earnings of college graduates years after leaving school solidify the findings that majors in humanities, education, and social sciences other than economics earn far less than do graduates in business and engineering. The salaries of business majors tend to catch up with those of engineers, but education and liberal arts majors remain far behind those with engi- 
neering and business degrees even when the quality of one's college is controlled. The seventh and eighth columns of Table 5 present data on the relationship between college major and yearly earnings of men from 21 to 70 years old from the 1967 Survey of Economic Opportunity. When college rank is held constant, undergraduate business majors earned $31 \%$ more, and engineers $51 \%$ more than humanities majors. Men with master's degrees in business or engineering earned $62 \%-65 \%$ more than those with a bachelor's degree in humanities (U.S. Bureau of the Census, 1967). The ninth column of Table 5 presents 1984 data on monthly earnings by major for men and women combined. ${ }^{13}$ Physical science majors earned $93 \%$ more, engineers earned $114 \%$ more, and business majors $103 \%$ more than did humanities majors. Workers with master's degrees in an engineering field earned 2.69 times as much, and MBAs earned 2.98 times as much as those with bachelor's degrees in humanities. Education majors earned slightly less than humanities majors. ${ }^{14}$

These large differentials by college major remain even when one controls for family background and life goals expressed in high school. The fifth and sixth columns of the table present estimates of the effects of college major on 1979 hourly earnings of young men and women who had graduated from high school in 1972 (Daymont \& Andrisani). They controlled for family background and the student's preferences regarding life goals (e.g., the importance of being wealthy and of helping others). Humanities, social science, and education majors received the lowest wages. Male engineers obtained 34\% more than did male humanities majors. Male business majors were paid $13 \%$ more. Female engineers were paid $27 \%$ more than female humanities majors, and female business majors were paid $25 \%$ more. Clearly, the market values some of the skills developed in college much more highly than others.

Partly because of these large wage differentials, there has been a dramatic growth in the relative supply of graduates in engineering, computer science, and business administration. In 1973, degrees in education, humanities, and social science accounted for
$50.5 \%$ of bachelor's degrees awarded to men and $83.5 \%$ of the bachelor's degrees awarded to women. By 1986 these percentages had dropped to $35.1 \%$ and $54.7 \%$, respectively. For males, degrees in engineering, computer science, and business, which accounted for $33.2 \%$ of all BAs in 1973 , rose to $50.8 \%$ of all bachelor's degrees in 1986. For women, degrees in engineering, computer science, and business grew from $3.5 \%$ to $26.6 \%$ of degrees awarded. As a result, the ratio of degrees awarded in engineering and computer science to degrees awarded in humanities, social science or education grew $5.2 \%$ per year in the 1970 s and $10.7 \%$ per year in the 1980s. The ratio of business degrees to humanities, social science, and education degrees grew $5.8 \%$ per year in the 1970 s and $5.1 \%$ in the $1980 \mathrm{~s}$.

The very rapid growth during the last 20 years of the relative supply of college graduates trained in business and engineering fields has surprisingly not significantly diminished the wage premiums that these fields command. Trends in wage premiums for business and technical degrees can be followed by comparing the first four columns of Table 5. Relative to humanities majors, wage premiums for engineering degrees grew dramatically during the 1970 s and then dropped slightly by 1989 , but they remained significantly above the levels that had prevailed in the 1960s. Wage premiums for chemistry and mathematics majors over humanities majors rose from $17 \%$ in the 1960 s to $36 \%$ in 1979 1980 and then fell to $23 \%$ in 1989 . Starting wage premiums for those with bachelor's degrees in business rose from essentially zero in the 1960 s to $10 \%-11 \%$ percent during the late 1970 s and 1980s. The starting wage premium for master's level training in business and engineering also appears to be substantially greater now than it was in the 1960s.

Trends in the effect of college major on salaries of college graduates who have been working for many years can be examined by comparing columns 8 and 9 of Table 5. These data suggest that the premiums for training in business and technical fields were significantly higher in 1984 than in 1967. The evidence is nearly overwhelming. The economic payoff to business and technical education is 
TABLE 5

Wage Premiums by College Major (Relative to Bachelor's Degree in Humanities)

\begin{tabular}{|c|c|c|c|c|c|c|c|c|c|}
\hline \multirow[b]{3}{*}{ Degree and major } & \multirow{2}{*}{\multicolumn{4}{|c|}{$\begin{array}{c}\text { Starting salaries } \\
1963-89^{\mathrm{a}}\end{array}$}} & \multirow{2}{*}{\multicolumn{2}{|c|}{$\begin{array}{c}\text { Hourly earnings } \\
\text { of } 25 \text {-year-olds in } \\
1979^{b}\end{array}$}} & \multicolumn{2}{|c|}{$\begin{array}{l}\text { Median earnings } \\
\text { males age } 21-70 \\
\text { BAs in } 1966^{c}\end{array}$} & \multirow{3}{*}{$\begin{array}{l}\text { Average monthly } \\
\text { earnings of both } \\
\text { sexes in } 1984^{\mathrm{d}} \\
\end{array}$} \\
\hline & & & & & & & \multirow{2}{*}{$\begin{array}{l}\text { Medium } \\
\text { rank } \\
\text { college }\end{array}$} & \multirow{2}{*}{$\begin{array}{l}\text { All col- } \\
\text { leges }\end{array}$} & \\
\hline & '63 & '69-'70 & '79-'80 & '89 & Male & Female & & & \\
\hline \multicolumn{10}{|c|}{ Bachelor's in low-wage major } \\
\hline Humanities & 0 & 0 & 0 & 0 & 0 & 0 & 0 & 0 & 0 \\
\hline Social sciences & & & & & 2 & 5 & 15 & 14 & - \\
\hline Economics & - & - & 8 & 15 & NSA & NSA & NSA & NSA & 111 \\
\hline Other & 0 & 0 & -1 & -1 & NSA & NSA & NSA & NSA & 28 \\
\hline Education & - & - & - & -13 & -4 & 5 & 2 & -9 & -6 \\
\hline Biological sciences & - & - & - & 23 & 0 & 28 & 4 & -11 & 12 \\
\hline Agriculture & - & - & - & -2 & NSA & NSA & NSA & NSA & 45 \\
\hline Health & - & - & - & 36 & NSA & NSA & - & - & 12 \\
\hline \multicolumn{10}{|c|}{ Bachelor's in high-wage major } \\
\hline Physical science & 17 & 17 & 36 & 23 & 15 & 35 & 31 & 28 & 93 \\
\hline Mathematics & 18 & 15 & 36 & 23 & NSA & NSA & NSA & NSA & 68 \\
\hline
\end{tabular}




\begin{tabular}{|c|c|c|c|c|c|c|c|c|c|}
\hline Engineering & & & & & 34 & 27 & 51 & 52 & 114 \\
\hline Chemical & 23 & 28 & 67 & 53 & NSA & NSA & NSA & NSA & NSA \\
\hline Electrical & 27 & 24 & 56 & 43 & NSA & NSA & NSA & NSA & NSA \\
\hline Industrial & 20 & 21 & 53 & 38 & NSA & NSA & NSA & NSA & NSA \\
\hline Mechanical & 24 & 23 & 57 & 42 & NSA & NSA & NSA & NSA & NSA \\
\hline Computer science & - & - & 44 & 33 & 19 & 13 & - & - & NSA \\
\hline Business & & & & & 13 & 25 & 32 & 28 & 103 \\
\hline Accounting & 10 & 17 & 21 & 21 & NSA & NSA & NSA & NSA & NSA \\
\hline Other & 0 & 2 & 11 & 10 & NSA & NSA & NSA & NSA & NSA \\
\hline Master's in business admin..$^{\mathrm{e}}$ & 27 & 47 & 66 & 58 & - & - & - & 62 & 198 \\
\hline Master's in engineering ${ }^{f}$ & 50 & 45 & 78 & 67 & - & - & - & 65 & 169 \\
\hline
\end{tabular}

Note. Dashes mean that data are not available; NSA means that data are not separately available.

aPercentage differential between the starting salary in the designated major over that received by humanities majors (College Placement Council CPC, 1985, 1989).

'Percentage differential implied by regressions predicting hourly wage rate of college graduates who have been out for about three years, controlling for degree and preferences, and using 1,835 observations from class of 1972 data (Daymont \& Andrisani, 1984).

'Percentage differential for median yearly earnings of male BA holders with designated major (and MBAs and master's in engineering) relative to median earnings of humanities majors (U.S. Bureau of the Census, 1967).

${ }^{\mathrm{d}}$ Percentage differential for mean monthly earnings of BA holders with designated major (and MBAs and master's in engineering) relative to earnings of humanities and liberal arts majors (U.S. Bureau of the Census, 1987, p. 13).

${ }^{\circ} \mathrm{CPC}$ starting salary data are for MBAs with nontechnical undergraduate degrees and less than one year of work experience before starting the program

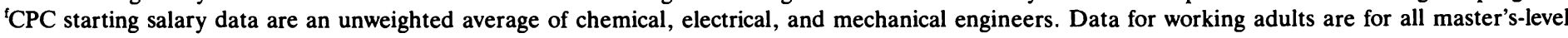
engineers combined. 
considerably greater than the payoff to majors in the humanities and social sciences other than economics, and the advantage of these fields of study has not diminished appreciably in the face of the massive increase in the number of students choosing these fields of study. Clearly, there has been a substantial shift in market demand favoring graduates with business and technical degrees over graduates with liberal arts and education degrees.

\section{Policy Implications of the Skills Shortage}

For policy, what matters is (a) the balance between current supply and current demand as indicated by the magnitude of the college wage premium, (b) the balance between forecast growth of supply and forecast growth of demand, and (c) the magnitude of the changes in wage premiums necessary to bring forecast differences in supply and demand into ex post equilibrium. Let us begin by examining the current balance between supply and demand. The wage premiums for obtaining a college degree grew substantially during the 1980 s and are now at historic highs. This implies that either the demand for college graduates grew more rapidly than did supply, or the demand for high school graduates grew much less rapidly than their supply. Either way, social rates of return to a college education have seldom been higher. This implies that public policies which increase college attendance and completion (e.g., better academic preparation in high school, low tuition at state colleges, and larger grants for needy students) now yield larger benefits than ever before.

\section{Possible Market Responses to the Skill Shortage}

The growing shortage of professionally trained workers and the rising skill premiums will tend to cause supply to increase more rapidly than we have projected. But the gap between the projected growth of demand and supply is quite large. Just to maintain the balance between the growth of supply and the growth of occupational demand that prevailed in the 1980 s, itself a period of shortage, the growth rate of college graduate labor supply must increase by $0.51 \%$ per year. This involves increasing the stock of college graduate workers 2.28 million above the level projected for the year 2000 , or put another way, a $286,000(29 \%)$ increase in the annual flow of bachelor's degree recipients into the labor force between 1992 and the year 2000 . Even if an increase in the supply of college graduates of this magnitude were to occur, it would not prevent further increases in the college wage premium. All it is likely to do is slow the rate of increase.

College attendance and graduation rates have risen recently in no small measure because of the strong market for college graduates. Our projections take past response into account and in addition forecast a further $5 \%-10 \%$ increase in the ratio of BAs to 22 24-year-olds during the latter half of the 1990s. Even much larger responses to the improved incentives would not change the basic situation; a 15\%-20\% increase rather than a $5 \%-10 \%$ increase in college graduation rates, for example, would raise the number of college graduates by only 100,000 annually and reduce the number of workers with 12 or fewer years of schooling by a similar amount.

Another possible natural market response to the strong demand for college graduates is further increases in labor force participation rates. The participation rate of male college graduates from 25 to 54 years old was $96.7 \%$ in 1988; thus there is not much room for an increase. Participation rates for female college graduates from 25 to 54 years old were $81.5 \%$, and so significant increases in labor supply are possible here. A $5 \%$ increase in labor force participation rates of women with a college degree would increase the supply of college graduate labor by 850,000 in the year 2000 (an increment of 106,000 per year between 1992 and 2000). Still another way to increase labor supply is to postpone retirement. In 1988 labor force participation rates for 60-64-year-old college graduates were $65 \%$ for males and $46 \%$ for females. Phasing in a two-year increase in the age at which all college graduates retire would have the same impact as an 81,000 increase in the annual number of BAs awarded between 1992 and 2000. Even if all three of these possibilities became reality by the year 2000 (and there is 
no guarantee that any of these responses will occur), there would still be strong labor market pressures for further increases in college wage premiums.

\section{Possible Policy Responses}

The social returns to a college education are extremely high and are likely to go even higher. Supply responses to the strong market do not appear to be sufficient to prevent a continuation of the current escalation of college wage premiums. If wage premiums for college-educated workers continue to escalate, inequality will continue to grow, American corporations will be at a competitive disadvantage, and multinational corporations will probably transfer offshore functions which intensively employ college graduates, for example, research, product development, design, and marketing. Hewlett-Packard recently announced, for example, the relocation of the headquarters of its personal computer division from the United States to Grenoble, France. The resulting escalation of wage premiums for professional and managerial workers will probably slow down the growth of these occupations, and our projections may well not be realized. Absent a policy response to stimulate the supply of college graduates, difficulties in recruiting highly skilled workers will force the economy off the upskilling path generated by the growth scenarios we have simulated, and the rapid upskilling of the 1970s and 1980s may slow considerably.

Education is a public function, and a public policy response to the shortage appears to be in order. Cost-effective ways of stimulating a substantial increase in the supply of college graduates are needed. Probably the most cost-effective way of ameliorating the short- age is to change immigration policy. There is a long queue of university graduates (many already fluent in English and some with degrees from American universities) seeking permanent residence in the United States, and it requires only a change in immigration policy to double the number of college educated immigrants to 200,000 a year. ${ }^{15}$ If total immigration were held constant, the supply of workers with limited amounts of education would be reduced simultaneously.

The number of American-born college graduates can be increased by strengthening academic standards in high schools, by reducing the very high dropout rates in American colleges, ${ }^{16}$ by encouraging adults to return to college to complete their degrees, by keeping public tuition levels low, and by shortening the time required to get a degree by expanding Advanced Placement programs in high schools and encouraging college students to take courses during summers. The "increase the home-grown supply" approach has two advantages: (a) because college training occurs in the United States, it will probably be adapted to the requirements of American jobs, and (b) the number of unskilled workers is decreased at the same time as the number of skilled workers is increased.

It appears that the market will be able to absorb even larger numbers of graduates in business and engineering without significant trouble. Therefore, public policy should not attempt to discourage this shift of students into business and engineering and should, in fact, facilitate it by focusing special effort on improving math, science, and economics instruction in the hope of increasing the pool of students entering scientific, technical, and business careers.

\section{(Appendixes follow)}




\begin{tabular}{lrrr}
\hline Occupation & $\begin{array}{r}\text { OES } \\
(\%)\end{array}$ & $\begin{array}{r}\text { CPS } \\
(\%)\end{array}$ & $\begin{array}{r}\text { OES-CPS } \\
(1,000 s)\end{array}$ \\
\hline Major & 10.25 & 12.37 & $-2,112$ \\
$\quad$ Executive \& administrative & 12.99 & 13.02 & -346 \\
$\quad$ Professional & 3.27 & 3.06 & 346 \\
Technical & 5.08 & 6.63 & $-1,614$ \\
High-level sales & 6.19 & 5.33 & 1,183 \\
Retail sales & 17.84 & 15.89 & 2,808 \\
Clerical & 1.80 & 1.69 & 185 \\
Protective service & 0.76 & 0.79 & -7 \\
Private household & 13.08 & 10.85 & 2,969 \\
Other services & 11.99 & 11.89 & 495 \\
Precision production, craft & 6.33 & 7.06 & -604 \\
Machine operators & 3.90 & 4.20 & -219 \\
$\quad$ Transportation operators & 4.14 & 4.23 & 28 \\
Laborers & 1.07 & 1.12 & -14 \\
Farming, forestry, \& fishing & & & \\
$\quad$ Owners \& managers & 1.89 & 1.87 & +80 \\
$\quad$ Laborers & 100.00 & 100.00 & 3,136 \\
$\quad$ Total & & & \\
High skill & 25.91 & 28.41 & $-2,112$ \\
$\quad$ Professional, technical, \& managerial & 30.99 & 35.04 & $-3,726$ \\
Professional, technical, \& managerial and sales representatives and & & & \\
$\quad$ managers & & & \\
Low skill & 31.90 & 30.69 & 2,396 \\
Operatives, laborers, farm laborers, and service workers & 38.09 & 36.02 & 3,579 \\
Operatives, laborers, farm laborers, service workers, and retail & & & \\
$\quad$ sales clerks & & & \\
\hline
\end{tabular}

Note. OES = Occupational Employment Survey; CPS = Current Population Survey.

\section{APPENDIX B}

\section{Projection Methods and Analysis of Trends}

The growth of occupational employment shares was assumed to follow a logistic growth path. The logistic function was assumed to have a ceiling of $20 \%$. The ceiling was set at the rather low $20 \%$ level because this fit the data slightly better than a ceiling set at $25 \%$ and because it would build in a slow down in the rate of growth for three largest fast-growing occupations-managers, professionals and sales workers. In our preferred model, the log of the ratio of the $j$ th occupation's share of employment in year $t$ to .2 minus that same occupational share, $\left[S_{j t} /\left(.2-S_{j t}\right)\right]$, is assumed to depend on the year $\left(T_{t}\right)$, the unemployment rate $\left(U_{t}\right)$, and one or more structural variables, $\left(X_{t}\right)$, intended to capture the influence of the economic changes that have occurred in the 1980s. The independent variables have been defined relative to their projected value in the year 2000 .

$$
\begin{gathered}
\log \left[S_{j t} /\left(.20-S_{j t}\right)\right]=a_{0}+a_{1}\left(T_{t}-2000\right)+ \\
a_{2}\left(\mathrm{U}_{t}-.055\right)+a_{3}\left(X_{t}-X_{2000}\right) \\
t=1972 \ldots 1989
\end{gathered}
$$

For three smallest occupations-farm workers, protective service workers and private household workers $-X_{t}$ is a trend shift variable for the years after 1980. For the other 10 occupations, the $X$ variables were the ratio of the merchandise trade deficit to gross national product (GNP), $\left(T R A D E F_{t}\right)$, and the ratio of personal computers used in business to civilian employment, $\left(P C U S E_{t}\right) .{ }^{17}$ The advantage of deviating all independent variables from their projected level in the year 2000 is that the intercept term, $a_{0}$, then provides an estimate of the forecast logit of the $j$ th occupation's share of employment in the year $2000 .{ }^{18}$ The means and standard deviations of the variables are given in Tables $\mathrm{B} 1$ and $\mathrm{B} 2$.

The estimation results for the 13 occupational categories are presented in Table B3. $T$ statistics are located in parentheses under the coefficient. The final column of the table contains the multiplier for calculating the proportionate impact on 
TABLE B1

Means and Standard Deviations of Independent Variables

\begin{tabular}{lccc}
\hline $\begin{array}{l}\text { Independent } \\
\text { variables }\end{array}$ & $M$ & $S D$ & $\begin{array}{c}M \\
\text { deviated } \\
\text { from value } \\
\text { in 2000 }\end{array}$ \\
\hline Year & 1980.5 & 5.30 & -19.51 \\
Unemployment rate & .0689 & .0140 & .0139 \\
Year $>80$ & 4.5 & 3.185 & -17.5 \\
Trade deficit & .01506 & .01263 & .01506 \\
PC use & .04896 & .06925 & -.40104 \\
\hline
\end{tabular}

Note. $\mathrm{PC}=$ personal computer.

that occupation's 1989 share of a unit change in an independent variable.

Managers, professionals, technicians, and clerical workers have large positive coefficients on the trend variable. The occupational shares of sales workers and service workers has been growing but only very slowly. Shares for craft workers and protective service workers share of employment were fairly stable through 1980 . The shares of all other occupations fell. Declines were quite rapid for operatives, private household workers and farmers.

The employment shares of craft, operative, and laborer occupations rise strongly during booms and decline during recessions. A one percentage point rise in unemployment decreases the laborer share of total employment by $2.2 \%$, the transportation operative share by $1.1 \%$, the factory operative share by $3.7 \%$, and the craft share by $1 \%$. Managers and clerical workers experience more modest share declines during recessions. Profes- sionals, technicians, sales workers, and service workers gain in share of total employment during recessions.

Trade deficits reduce the occupational share of factory operatives, laborers and managers and increase the shares of sales workers and craft workers. The coefficients on the trade deficit imply that the switch from a merchandise trade surplus of $0.7 \%$ of GNP in 1976 to a trade deficit of $3.6 \%$ of GNP in 1987 decreased factory operative employment shares by $11 \%$ and increased precision production and craft employment shares by $5 \%$. The business press appears to have been correct when, in the face of rising aggregate employment of managers, it pointed to losses of managerial jobs resulting from the recession and the loss of international competitiveness and the strong dollar. Compared with the cutbacks in factory operative jobs, however, the resulting managerial layoffs were modest indeed. Because the overall upward trend of the managerial employ-

TABLE B2

Means, Standard Deviations, and Final Value of Independent Variables

\begin{tabular}{lcccc}
\hline Dependent variables & $\begin{array}{c}\text { Arithmetic } \\
M\end{array}$ & $S D$ & $\begin{array}{c}\text { Value in } \\
1989\end{array}$ & $\begin{array}{c}\text { Mean of } \\
\text { logit }\end{array}$ \\
\hline Managers & .1050 & .0112 & .1265 & .1029 \\
Professionals & .1203 & .0081 & .1325 & .4152 \\
Technicians & .0279 & .0027 & .0311 & -1.824 \\
Sales & .1120 & .0064 & .1319 & .2422 \\
Clerical & .1617 & .0028 & .1569 & 1.441 \\
Craft & .1234 & .0031 & .1176 & .4767 \\
Factory operative & .0864 & .0129 & .0703 & -.2771 \\
Transportation operative & .0451 & .0032 & .0416 & -1.2356 \\
Laborer & .0477 & .0055 & .0417 & -1.1673 \\
Private household & .0113 & .0028 & .0074 & -2.8428 \\
Protective service & .0157 & .00082 & .0167 & -2.4646 \\
Other service & .1063 & .0034 & .1084 & .1270 \\
Farm & .0374 & .0054 & .0292 & -1.4785 \\
\hline
\end{tabular}


TABLE B3

Determinants of Occupational Employment Shares for 1972-1989 Logit Model With Ceiling of 20\%

\begin{tabular}{|c|c|c|c|c|c|c|c|c|c|}
\hline Major occupation & Trend & Unemp. & $\begin{array}{l}\text { Trade } \\
\text { deficit }\end{array}$ & PC use & Trend $>80$ & Intercept & $M S_{e}$ & $R^{2}$ & $\begin{array}{c}\text { Proportion } \\
\text { multiplier }\end{array}$ \\
\hline Managers & $\begin{array}{l}.0407^{* * *} \\
(13.86)\end{array}$ & $\begin{array}{c}-1.293^{* *} \\
(2.95)\end{array}$ & $\begin{array}{c}-2.78^{* * *} \\
(3.97)\end{array}$ & $\begin{array}{c}0.618^{* * *} \\
(3.58)\end{array}$ & & $\begin{array}{l}1.204 \\
(27.72)\end{array}$ & .0174 & .996 & .246 \\
\hline Professionals & $\begin{array}{l}.0227^{* * * *} \\
(8.82)\end{array}$ & $\begin{array}{l}3.599 * * * \\
(9.36)\end{array}$ & $\begin{array}{r}-0.258 \\
(.42)\end{array}$ & $\begin{array}{l}0.657^{* * *} \\
(4.34)\end{array}$ & & $\begin{array}{l}1.075^{* *} \\
(28.23)\end{array}$ & .0152 & .994 & .277 \\
\hline Technicians & $\begin{array}{l}.0304^{* * * *} \\
(9.46)\end{array}$ & $\begin{array}{l}0.923^{*} \\
(1.92)\end{array}$ & $\begin{array}{r}-1.607^{*} \\
(2.10)\end{array}$ & $\begin{array}{c}-0.610^{* * *} \\
(3.22)\end{array}$ & & $\begin{array}{c}-1.465^{* * *} \\
(30.80)\end{array}$ & .0190 & .979 & .817 \\
\hline Sales & $\begin{array}{l}.0057 \\
(1.19)\end{array}$ & $\begin{array}{l}2.246^{* * * *} \\
(3.22)\end{array}$ & $\begin{array}{l}4.233^{* * *} \\
(3.67)\end{array}$ & $\begin{array}{c}0.761^{* *} \\
(2.67)\end{array}$ & & $\begin{array}{c}0.564^{* * *} \\
(7.89)\end{array}$ & .0286 & .964 & .341 \\
\hline Clerical & $\begin{array}{l}.0359^{* * *} \\
(3.64)\end{array}$ & $\begin{array}{c}-0.747 \\
(.51)\end{array}$ & $\begin{array}{r}-4.437^{*} \\
(1.88)\end{array}$ & $\begin{array}{c}-2.372^{* * *} \\
(4.07)\end{array}$ & & $\begin{array}{c}1.268^{* * *} \\
(8.67)\end{array}$ & .0585 & .696 & .216 \\
\hline Craft & $\begin{array}{r}-.0056 \\
(1.18)\end{array}$ & $\begin{array}{c}-2.338^{* * *} \\
(3.28)\end{array}$ & $\begin{array}{l}3.088^{* * *} \\
(2.71)\end{array}$ & $\begin{array}{c}-0.803^{* * *} \\
(2.86)\end{array}$ & & $\begin{array}{c}-0.0308^{* * *} \\
(.44)\end{array}$ & .0282 & .859 & .412 \\
\hline Factory operatives & $\begin{array}{c}-.0253^{* * *} \\
(6.13)\end{array}$ & $\begin{array}{c}-5.703^{* * *} \\
(9.25)\end{array}$ & $\begin{array}{c}-3.934^{* * *} \\
(4.00)\end{array}$ & $\begin{array}{c}-1.201^{* * *} \\
(4.94)\end{array}$ & & $\begin{array}{c}-1.113^{* * *} \\
(18.23)\end{array}$ & .0244 & .992 & .649 \\
\hline Transportation operatives & $\begin{array}{c}-.0175^{* * *} \\
(5.22)\end{array}$ & $\begin{array}{c}-1.373^{* * *} \\
(2.73)\end{array}$ & $\begin{array}{r}-0.10 \\
(.13)\end{array}$ & $\begin{array}{r}0.139 \\
(.70)\end{array}$ & & $\begin{array}{c}-1.501^{* * *} \\
(30.16)\end{array}$ & .0199 & .954 & .792 \\
\hline Laborers & $\begin{array}{c}-.0234^{* * *} \\
(3.86)\end{array}$ & $\begin{array}{c}-2.738^{* * *} \\
(3.02)\end{array}$ & $\begin{array}{r}-1.175 \\
(.81)\end{array}$ & $\begin{array}{r}-0.033 \\
(.09)\end{array}$ & & $\begin{array}{c}-1.581^{* * *} \\
(17.62)\end{array}$ & .0359 & .957 & .791 \\
\hline Private household & $\begin{array}{c}-.0580^{* * *} \\
(12.34)\end{array}$ & $\begin{array}{c}0.451 \\
(.59)\end{array}$ & & & $\begin{array}{r}.0196 * * \\
(2.48)\end{array}$ & $\begin{array}{c}-3.638^{* * *} \\
(61.62)\end{array}$ & .0367 & .983 & .963 \\
\hline Protective service & $\begin{array}{r}-.002 \\
(.08)\end{array}$ & $\begin{array}{l}1.806^{* * * *} \\
(4.35)\end{array}$ & & & $\begin{array}{c}.0162 * * * \\
(3.76)\end{array}$ & $\begin{array}{c}-2.210^{* * *} \\
(68.55)\end{array}$ & .0200 & .897 & .916 \\
\hline Other service & $\begin{array}{c}.0086^{* *} \\
(2.30)\end{array}$ & $\begin{array}{l}2.319^{* * *} \\
(4.14)\end{array}$ & $\begin{array}{l}1.239 \\
(1.38)\end{array}$ & $\begin{array}{r}-0.110 \\
(.50)\end{array}$ & & $\begin{array}{c}0.200^{* * *} \\
(3.61)\end{array}$ & .0222 & .920 & .458 \\
\hline Farm & $\begin{array}{c}-.0421^{* * *} \\
(18.00)\end{array}$ & $\begin{array}{l}2.404^{* * * *} \\
(6.36)\end{array}$ & & & $\begin{array}{c}.0157^{* * * *} \\
(3.99)\end{array}$ & $\begin{array}{c}-2.059 * * * \\
(70.09)\end{array}$ & .0183 & .991 & .854 \\
\hline
\end{tabular}

Note. Unemp. $=$ employment; $\mathrm{PC}=$ personal computer. Top value is coefficient; value in parentheses is $t$ statistic.

${ }^{*} p<.05 .{ }^{* *} p<.025 .{ }^{* * *} p<.01$. 
ment is so strong (1\% per year in 1989), these setbacks turned out to be temporary. Almost all of the growth of managerial jobs has been outside of manufacturing.

The effects of the microcomputer revolution and the associated reorganization of manufacturing were tested by including the ratio of personal computers used in business to civilian employment, $\left(\mathrm{PCUSE}_{t}\right)$, in the preferred model for most occupations. The microcomputer revolution appears to have had a substantial negative effect on the employment share of technicians, clerical workers, machine operatives and craft workers. The results imply that the rise in PCUSE from zero in 1978 to $18 \%$ in 1988 lowered factory operative employment by $14 \%$, craft employment by $6 \%$, and technician and clerical employment by $9 \%$. These machines have resulted in a large decline in the demand for board drafters and have improved labor productivity in a host of other technical and clerical occupations. Electrical and electronic technicians and health technicians, both of which grew at a torrid $7.2 \%$ per year between 1972 and 1982, slowed to yearly rates of only $0.5 \%$ and $3.1 \%$, respectively, between 1982 and 1989. The occupations that gained share as a result of the microcomputer revolution were managers, professionals, and sales occupations. Employment in sales grew more rapidly in the 1980s than in the 1970s largely because of the trade deficit and increased use of microcomputers.

Three occupations-farmers, private household workers, and protective service workerswere best represented by a simpler model which simply allowed for a trend shift in 1980 . In the case of farmers and private household workers the trend shift implied a slowdown in their rate of decline. For protective service workers, the trend shift implies that its share was rising nearly $1.5 \%$ per year during the 1980s.

What do these estimation results tell us about the future? This, of course, depends on future levels of unemployment, the trade deficit, and PC use. Because the foreign debt of the United States cannot grow at current rates indefinitely and the growing debt must eventually be serviced by exporting more goods than are imported, our projections assume that merchandise trade will be in balance in the year 2000. It was further assumed that unemployment will be $5.5 \%$ and that PCUSE will increase from its 1989 level of $21 \%$ to $45 \%$ in 2000 . The intercept terms of the equations provide an estimate of the forecast $S_{j t} /\left(.2-S_{j t}\right)$ from which the share of employment for each occupation may be calculated.

Our forecasts of occupational growth are presented in the fifth column of Table 3. We forecast strong increases in demand for managers, professionals, technicians, and sales workers and abso- lute declines in the number of craft workers, operatives, laborers, farm workers, and private household workers. Clerical and service jobs are projected to grow but at the rate that is slightly below the growth of total employment.

Some sales occupations require a great deal of education and training - for example, sales representatives in manufacturing, finance, communications, and professional services-and others such as sales clerks in retailing and personal services require very little. Which type of sales job is growing most rapidly? When the share of sales workers who are sales clerks in the retail and personal service sector is regressed on time, a significant negative coefficient is obtained, suggesting that low-skill sales jobs grew less rapidly than high-skill sales jobs in the 1980s (see Table B4). However, the shakeout in the financial sector has slowed the growth of sales workers in that industry, and the sales clerk share has been stable since 1987. Consequently, we project the sales clerk share of sales jobs in 2000 to be the same as it is in 1988 .

Growth rates differ across sales occupations. This was determined by regressing the share sales job that were (a) sales clerks in retail and personal services (including other sales occupations), (b) sales representatives in finance and business services, (c) sales representatives selling commodities, and (d) supervisors and proprietors on time. The data conformed to the occupational definitions introduced in 1982. The results are given below:

$$
\begin{gathered}
\left(\text { SalesClerk }_{t} / \text { SALES }_{t}\right)=.4117 \\
-\quad .003136\left(\text { YEAR }_{t}-2000\right) \\
(4.21)
\end{gathered}
$$

$t=1982-1990, R^{2}=.717$

$\left(\right.$ SalesFin $_{t} /$ SALES $\left._{t}\right)=.1883$

$$
\begin{aligned}
& .001611\left(\text { YEAR }_{t}-2000\right) \\
& (2.38) \\
t=1982-1990, & R^{2}=.448
\end{aligned}
$$$$
\left(\text { SalesManag }_{t} / \text { SALES }_{t}\right)=.3084
$$$$
+.003303\left(\mathrm{YEAR}_{t}-2000\right)
$$$$
\text { (14.19) }
$$$$
t=1982-1990, R^{2}=.966
$$$$
\left(\text { SalesCommod }_{t} / \text { SALES }_{t}\right)=.09185
$$$$
\text { - .001761 }\left(\text { YEAR }_{t}-2000\right)
$$$$
\text { (5.94) }
$$

(2)




$$
\begin{gathered}
\left(\text { FarmOper }_{t} / \text { FarmWkr }_{t}\right)=.3486 \\
-.002662\left(\text { YEAR }_{t}-2000\right) \\
\quad(2.72) \\
t=1982-1990, R^{2}=5.14
\end{gathered}
$$

\section{Notes}

The research reported here was supported by funds from the Center for Advanced Human Resource Studies, the Center on the Educational Quality of the Workforce, and a New York State Fellowship for Minority Graduate Students. This article has benefited from conversations with Ron Kutscher and other staff at the Department of Labor. The opinions and conclusions expressed herein are solely those of the authors and should not be construed as representing the opinions or policies of any agency of the United States government.

${ }^{1}$ For managers, this involved adding accountants, personnel, and labor relations workers and inspectors, not elsewhere classified, to both the 1978 base and the 1990 projection. For professional workers, it involved adding decorators, window dressers, and health trainees and subtracting accountants, personnel and labor relations workers, computer programmers and sales engineers (Green, Dinh, Priebe, \& Tucker, 1983). When separate data were not available for some of the smaller occupations that were reclassified, they were left in the major group they had been prior to 1983. Using the 1980 census classification system in Klein (1984), the BLS has published CPS-based yearly estimates of employment by major occupation all the way back to 1972 . This data series was used to calculate actual percentage rates of growth and actual shares of employment growth. Thus, percentage growth calculations are based on definitions of major occupation that are consistent over time, but there are slight differences in the detailed occupations included in a major occupation for the two calculations. The data on 1989 employment are from January, 1990, Employment and Earnings.

${ }^{2}$ The ratio of OES and CPS estimates of aggregate occupational employment were calculated for both 1988 and 1978. Changes in these ratios were then used to construct an estimate of 1978-1989 occupational employment growth based on OES data. The causes of this very rapid increase in the number of managerial jobs are the subject of Carter's master's thesis. The initial findings are that substantially over half $(74 \%$ of the growth in the 1983-1989 period) of these additional jobs were filled by women. Women, who accounted for only $17.6 \%$ of managers in 1972 , now account for $40 \%$ of the nation's managers. Another important finding is that almost all the growth of managerial jobs has been outside of manufacturing in industries where women now account for a large share of the man- agers such as professional services (57\%) and finance $(50 \%)$.

${ }^{3}$ The reasons for the downward bias in BLS projections of the growth of skilled jobs during the 1980s are discussed in detail in Bishop and Carter (1990). Two causes stand out: the failure to predict the large decline of employment in manufacturing and the failure to predict the substantial increases in the managerial and professional share of employment in many industries. BLS's forecasts of future staffing patterns must be extrapolated from Occupational Employment Survey (OES) data which are available only every three years and which have generally not been comparable from year to year. Complicating matters further was the change in the occupational classification system for the 1980 census, which was introduced into the CPS and the OES in 1982 and 1983. This meant that observed changes in staffing patterns between the 1970 and 1980 censuses could not be simply extrapolated into the future. It also meant that much of the data collected in the third and fourth waves of OES surveys were inconsistent with data collected prior to 1983 . Given these data problems and the BLS's focus on projecting over 500 different occupations, it is easy to see why BLS has not chosen to systematically extrapolate past trends in occupational staffing ratios derived from OES or census data into the future, but rather to rely on the judgment of analysts who can take data quality problems into account. Systems which rely on the judgment of analysts are inherently conservative, however. Sometimes the analysts feel that they are knowledgeable enough about the situation in a particular industry to project substantial changes in staffing patterns. But they perceived forecasting big changes in staffing patterns as "going out on a limb." The staff is small, and they cannot be experts on all industries and occupations. As one analyst described the situation, "In a lot of cases, if we did not know a lot about the occupation, we just left it alone." These problems also plague the projections published in 1987 and 1989.

${ }^{4}$ The BLS projections are presented in Silvestri and Lukasiewicz $(1987,1989)$ In order to maintain comparability of the BLS projections to the CPS data on actual employment growth, the percentage growth rates projected by the BLS for each major occupation group were applied to the CPS estimates of the number of workers in each occupation in 1986 and 1988. Because high-skill jobs account for a larger proportion of total employment in CPS data, this adjustment raises our estimates of BLS-projected share for high-skill jobs about 4-5 percentage points above the shares calculated directly from BLS publications. BLS's occupational projections are based on OES data collected from employers that count people with 
multiple jobs more than once. CPS data classify people rather than jobs and tend to classify multiple job holders into their highest level occupation. Between 1978 and 1988, low-skill jobs grew at the same rate in OES data as in CPS data. Mediumskill jobs grew more rapidly in the OES, and highskill jobs grew about $6 \%$ less rapidly.

${ }^{5}$ In 1989 median weekly wages for full-time wage and salary workers in sales jobs included in the high-skill category were $\$ 561$ for sales representatives, commodities except retail, $\$ 502$ for sales representatives in finance and business services, and $\$ 424$ for supervisors and proprietors. Median weekly wages for the other high-skill occupations were $\$ 583$ for managers, $\$ 586$ for professionals, and $\$ 475$ for technicians. In contrast, median weekly wages for the low-skill occupations were $\$ 235$ for sales workers in retail and personal services, \$253 for service occupations, and \$323 for operatives, fabricators, and laborers. Between 1983 and 1989 the ratio of high-skill occupation wages to low-skill occupation wages rose from 1.68 to 1.88 .

${ }^{6}$ The source of data on PC use is the U.S. Bureau of the Census Statistical Abstract: 1990 (pp. 759, 943-952). According to Future Computing, there were $20,330,000$ PCs in use in private business in 1988. An alternative source of data, the COMTEC survey of a stratified random sample of business, governmental, and nonprofit establishments, yields a substantially smaller estimate of the number of PCs in use. The 1989 COMTEC survey estimates that there were 9,693,000 microcomputers and 10,462,000 CRT terminals and dedicated word processors in use at work places outside of the education sector. (U.S. Bureau of the Census, 1990). The large discrepancy between these two data sources appears to be due to (a) the very low scrappage assumed by Future Computing, (b) inflation of sales figures by some of the vendors supplying data to Future Computing, (c) delays in the actual installation of the computers, (d) the allocation to business of some PCs that the COMTEC survey appears to place in schools, (e) the exclusion of zero employee firms and home offices from the COMTEC survey, and (f) problems with the Dun \& Bradstreet list of establishments. The Future Computing data series was used in the analysis because it is available for a longer span of time and because there did not appear to be a good way of extending the series on CRT terminals back into the 1970s. To project this variable 10 years into the future, we need an estimate of the possible extent of the eventual workplace market for these machines. Conventionally, comparisons are made with white-collar employment. The education industry needs to be excluded from both numerator and denominator because students, not teachers, are the primary users of PCs. Point-of-sale terminals are not included in the counts of PCs or workstations; thus, retail sales clerks also need to be excluded from the denominator. The Future Computing estimate of PCs is equal to $37.5 \%$ of the number of white-collar employees minus teachers and sales clerks. In COMTEC data, the ratio of PCs to white-collar employees who are not teachers or retail clerks was $17.4 \%$, and the ratio for workstations of all kinds was $35.5 \%$. To us, there appears to be considerable room for current levels of PC use to grow, so we assume that it doubles from current levels. The substitution of COMTEC data for Future Computing data does not change our forecasts for the year 2000 as long as one retains the assumption that the year 2000 impact of the PC will be slightly more than double its 1989 impact.

${ }^{7}$ Comparisons of percentage rates of change are much less sensitive to arbitrary assumptions regarding which jobs "require a college degree" than are comparisons between numbers of openings requiring a degree and the growth in numbers of college graduates. The BLS approach to comparing supply and demand depends critically on analyst judgments regarding which jobs require a degree now and which jobs will require a degree 10 years in the future. Our does not.

${ }^{8}$ Workers are divided into 15 major occupational groups: managerial, professional, technical, sales representatives and managers, sales clerks, clerical, craft, factory operatives, transportation operatives, handlers and laborers, private household workers, protective service workers, other service workers, farm owners and managers, and farm laborers.

${ }^{9}$ The source of data on the educational attainment of the labor force was the 1983 Handbook of Labor Statistics (U.S. Bureau of Labor Statistics, 1983, Table 65) and unpublished BLS data for 1988. Before 1972 the tabulations were for workers over the age of 18. After that date, tabulations were for workers over the age of 16 . Consequently, rates of change of educational attainment for the 1970 s are for the eight-year period from 1972 to 1980 , for which data are consistent over time.

${ }^{10}$ Comparisons of CPS estimates of increases in the number of college graduates in the population to estimates derived from data on bachelor's degrees awarded for period prior to 1980 suggest rough consistency. During the 1980 s, these two data sources diverge. The number of individuals born after 1935 claiming to have completed $16+$ years of schooling increased by $9,181,000$ between 1980 and 1988. During this eight-year period, there were only $6,543,000$ bachelor's degrees awarded in the United States. Immigration probably accounts for another 734,000 of this increase, and individuals with $16+$ years of schooling but no 
degree for another $1,019,000$. This leaves a remaining discrepancy of 885,000 that is probably due to increased misreporting of years of schooling. This means that the true growth rate of college graduate workers is not the $4.18 \%$ per year figure calculated directly from CPS data, but rather $3.76 \%$ per year that results from subtracting 885,000 from $26,814,000$, the 1988 CPS estimate of the number of college-graduate workers, when calculating the rate of gain between 1980 and 1988. This correction of the data helps explain why the college-graduate labor market tightened so dramatically during the $1980 \mathrm{~s}$. It also results in the 1990s looking more like the 1980s and thus reduces our estimates of the magnitude of the shortage during the 1990s.

${ }^{11}$ The no policy change projection of the increase in the stock of workers with 16 or more years of schooling was developed in the following manner. We project that an average of $1,001,000$ BAs will be awarded each year during the early 1990 s, a $3.7 \%$ increase from the level that prevailed from 1980 to 1987 (National Center for Education Statistics, 1989, Table 200). The number of 17 -year-olds is now $13 \%$ below its $1979 / 80$ peak and will fall another $10 \%$ by $1993-$ 1994. If educational policies and the payoff to attending college do not change, we do not project further increases in BAs awarded because the declining size of the 21-24-year-old age cohort is assumed to offset a projected $10 \%$ rise in the proportion of the age cohort that obtains a BA. Immigration of people with a college degree was about 100,000 per year in the first part of the 1980 s, and this flow is assumed to continue (data provided by George Borjas, personal communication, July, 1990). Adkins (1975) reports that for every 100 individuals with a BA degree there are about 12.5 individuals reporting 16 or more years of schooling without having a BA or first professional degree. Therefore, our estimate of the flow into the college-graduate category is obtained by multiplying 1.1 million by 1.125 . The share of the flow of new college graduates assumed to be employed was set equal to the labor force participation rate for this group, .90 . The result was a projection of $13,363,000$ individuals added to the stock of employed college graduates over the 12year period. In the March 1988 CPS, there were $3,018,000$ college graduates over the age of 65 ; $3,245,000$ between 55 and 64 ; and 4,982,000 between 45 and 54 years of age. Their labor force participation rates were .906 for 45 -54-year-olds, .706 for 55-64-year-olds, and .222 for those 65 and over (U.S. Bureau of Labor Statistics, 1988b). According to life tables, the estimated 10-year survival rate is .9083 for the $45-54$-year-old college graduates and .8136 for the 55-64-year-old group (U.S. Bureau of the Census, 1990). An estimate of the number of college graduates from the 45-64-year-old group in 1988 that are still in the labor force 10 years later was obtained by multiplying the population figures by the survival rate and then by the labor force participation rate for the next older group. Exits from the labor force for the 12-year period were estimated to be $1,585,000$ of the age 45-54 in 1988 group, 1,729,000 in the 55-64 in 1988 group, and 670,000 (all) of those over 65 in 1988. Thus, the projected net growth in the number of college graduates over the 12-year period is $9,379,000$ from a $26,812,000$ level in 1988. The BLS predicts an almost identical$9,105,000$-increase in the college graduate labor force (Sargent \& Pfleeger, 1990).

${ }^{12}$ The rate of skill upgrading during the 1980 s is slightly lower in OES data than in CPS data because professional jobs grew less rapidly in the OES than in the CPS. Because we project no change in skill upgrading rates during the 1990s, an OES-based forecast of skill upgrading during the 1990s will be somewhat lower than the one we present in Tables 2 and 4 . The forecast of continuing shortage of college graduates would not, however, be affected by using OES data on upskilling during the 1980s. The rise in relative wage rates of college graduates during the 1980 s establishes it as a period of shortage even if one revises the rate of growth of professional jobs downward. We project a more severe shortage in the 1990s than in the 1980 s because the rate of increase of supply of college graduates will necessarily fall below the rates that prevailed during the 1980 s.

${ }^{13}$ This information is from U.S. Bureau of the Census, Current Population Reports (1987). The very large differentials between the college majors found in these data reflect both differences in wage rates and in hours worked per month. If gender were controlled, the differentials would be smaller.

${ }^{14}$ Clearly, teachers are paid a great deal less than most other college graduates, and their disadvantage appears to have grown between 1967 and 1984. The remuneration of teachers is much greater in many other countries. In Australia, for example, 1981 starting salaries of college graduates was $\$ 18,484$ for education majors, $\$ 15,193$ for engineers, $\$ 14,314$ for computer science, and $\$ 16,390$ for economics. Regression analysis of this data indicates that when age, academic honors, locality, type of university, and college major are controlled for, those entering teaching are paid $\$ 1,691$ more than those going into government administration, and $\$ 540$ more than those entering a production or sales position. This information is from Miller and Volker (1983). No wonder it is so difficult in America to attract the best and brightest to the teaching profession. 
${ }^{15}$ In 1986-1987, nonresident aliens were awarded 29,306 bachelor's degrees, 29,898 master's degrees, and 6587 doctor's degrees from American universities. Nearly two-thirds of these degrees were in science, engineering, or business (National Center for Education Statistics, 1989). Jobs for the highly educated are so scarce in India that some PhDs are driving taxis. Hiring quotas favoring scheduled castes in India and Malays in Malaysia have prevented many highly educated individuals from obtaining work that utilizes their skills. The upsurge of anti-Semitism in the Soviet Union has stimulated a massive increase in emigration. American immigration policy denies these individuals the opportunity of coming to a country that could use their specialized skills and has plenty of vacant housing and forces them instead to go to a country that needs carpenters and mechanics, not violinists and mathematicians, and which does not have sufficient housing to absorb the influx. Although their skills would probably be better used in the United States than elsewhere, it must be recognized that many college-educated immigrants will not be able to find jobs that employ their college training. There are not many colleges or banks that want to hire Soviet-trained economists, for example. The impact of additional immigrants on the skills shortage will be maximized if priority is given to applicants who have an employer sponsor who will make use of their special skills.

${ }^{16}$ About $21 \%$ of the freshmen in October 1985 did not return the following fall, and $27 \%$ of the sophomores did not return next fall (National Center for Education Statistics, 1990, p. 26).

${ }^{17}$ The estimates of the number of PCs in use in business were made by Future Computing/ Datapro Inc. and were published in 1990 by the Bureau of the Census in the Statistical Abstract (pp. 943-952). They are derived by cumulating numbers of machines sold. A very low scrap rate of $3.4 \%$ to $6 \%$, depending on the year, was assumed. Where possible, vendor reports were used to allocate sales of computers between categories of end user-business, education, and home. Quite often, however, rules of thumb were used to make these allocations. Future Computing is no longer in business; thus more detailed information on how the series was constructed and data for 1989 are not available. Point estimates of PCs in use were made for 1989 and for $1979-1980$ by extrapolation.

${ }^{18} \mathrm{~A}$ number of alternative models were estimated in order to see how sensitive the results are to changes in functional form, specification, and in the scenario projected for the year 2000 . Such tests were needed because there were only 18 years of data on which to estimate the forecasting model, and theory did not yield only one plausible specification. The results of some of these tests are detailed in Bishop and Carter (1990), Although specification and scenario do affect projected occupational shares, all of the specifications yielded substantially larger increases in skilled jobs than the BLS projections. Other findings were robust with respect to specification and scenario as well.

\section{References}

Adkins, D. L. (1975). The great American degree machine (The Carnegie Foundation for the Advancement of Teaching). New York: McGrawHill.

Bishop, J., \& Carter, S. (1990). The deskilling vs. upskilling debate: The role of BLS projections (Center for Advanced Human Resource Studies Working Paper 90-14). Ithaca, NY: Cornell University.

Carey, M. (1981). Occupational employment growth through 1990. Monthly Labor Review, 104(8), 42-55.

College Placement Council. (1985). Inflation and the college graduate: 1962-1985. Bethlehem, PA: Author.

College Placement Council. (1989, September). CPC salary survey. Bethlehem, PA: Author.

Daymont, T. N., \& Andrisani, P. (1984). Job preference, college major and the gender gap in earnings. The Journal of Human Resources, 19(3), 408-428.

Freeman, R. (1976). The overeducated American. New York: Academic Press.

Freeman, R., \& Hansen, J. (1983). Forecasting the changing market for college-trained workers. In R. F. Taylor, H. Rosen, \& F. Pratzner (Eds.), Labor market demands (pp. 79100). Columbus, $\mathrm{OH}$ : National Center for Research in Vocational Education.

Green, G. P., Dinh, K. T., Priebe, J. A., \& Tucker, R. R. (1983). Revisions in the current population survey beginning in January 1983. Employment and Earnings, 30(2), 7-15.

Johnston, W. B., \& Packer, A. H. (1987). Workforce 2000: Work and workers for the 21st century. Indianapolis, IN: Hudson Institute.

Katz, L., \& Murphy, K. (in press). Changes in relative wages, 1963-1987: Supply and demand factors. Quarterly Journal of Economics.

Kirsch, I., \& Jungeblut, A. (1986). Literacy: Profiles of America's young adults. Princeton, NJ: National Assessment of Educational Progress, Educational Testing Service.

Klein, D. P. (1984). Occupational employment statistics for 1972-82. Employment and Earnings, 20(1), 13-16.

Levin, H., \& Rumberger, R. (1983). Educational implications of high technology (working pa- 
per). Stanford, CA: Institute for Research on Education Finance and Governance.

Levin, H., \& Rumberger, R. (1984). Forecasting the impact of new technologies on the future job market (working paper). Stanford, CA: Institute for Research on Education Finance and Governance.

Levin, H., \& Rumberger, R. (1987). Educational requirements for new technologies: Visions, possibilities, and current realities. Educational Policy, 1(3), 333-354.

Marenbach, D. (1973). Rates of return to education in the United States from 1939 to 1959. Doctoral dissertation, Stanford University.

Miller, P., \& Volker, P. (1983). Starting salaries and estimations of graduates in Australia (Conference Paper No. 14). Canberra, Australia: Bureau of Labor Market Research.

Mischel, L., \& Teixeira, R. (1991). The myth of the coming labor shortage: Jobs, skills and incomes of America's Workforce 2000. Washington, DC: Economic Policy Institute.

National Center for Education Statistics. (1989). Digest of education statistics: 1989. Washington, DC: U.S. Government Printing Office.

National Center for Education Statistics. (1990). The condition of education, 1990: Vol. 2. Postsecondary education. Washington, DC: U.S. Government Printing Office.

Norwood, J. (1979). The outlook for college graduates through 1990. Occupational Outlook Quarterly, 23(4), 2-7.

Sargent, J. (1982). The job outlook for college graduates during the 1980s. Occupational Outlook Quarterly, 26(2), 3-7.

Sargent, J. (1988). A greatly improved outlook for college graduates: A 1988 update to the year 2000. Occupational Outlook Quarterly, 32(2), 3-8.

Sargent, J., \& Pfleeger, J. (1990). 1988-2000Outlook for college graduates. Excerpts from an unpublished Bureau of Labor Statistics technical memorandum.

Silvestri, G., \& Lukasiewics, J. (1987). A look at occupational employment trends to the year 2000. Monthly Labor Review, 110(9), 37-49.

Silvestri, G., \& Lukasiewics, J. (1989). Projections of occupational employment, 1988-2000. Monthly Labor Review, 112(11), 42-65.

Silvestri, G., Lukasiewics, J., \& Einstein, M. F. (1983). Occupational employment projections through 1995. Monthly Labor Review, 106(11), 37-49.

U.S. Bureau of the Census. (1967). Characteris- tics of men with college degrees: 1967. Current population reports: Population characteristics (Series P-20, No. 201). Washington, DC: U.S. Government Printing Office.

U.S. Bureau of the Census. (1972). Effects of different reinterview techniques on estimates of simple response variance. Evaluation and research program of the U.S. censuses of population and housing, 1960 (Series ER-60, No. 11). Washington, DC: U.S. Government Printing Office.

U.S. Bureau of the Census. (1975). Historical statistics of the United States: Part 1. From colonial times to 1970 (Bicentennial Edition). Washington, DC: U.S. Government Printing Office.

U.S. Bureau of the Census. (1987). What's it worth? Educational background and economic status: Spring 1984. Current population reports (Series P-70, No. 11). Washington, DC: U.S. Government Printing Office.

U.S. Bureau of the Census. (1990). Computers in the office. Statistical abstract 1990. Washington, DC: U.S. Government Printing Office.

U.S. Bureau of Labor Statistics. (1983). Handbook of labor statistics. Washington, DC: U.S. Government Printing Office.

U.S. Bureau of Labor Statistics. (1984). Employment and Earnings, 31(1), 214.

U.S. Bureau of Labor Statistics. (1987). Employment and Earnings, 34(1), 177.

U.S. Bureau of Labor Statistics. (1988a). Employment and Earnings, 35(4), 30.

U.S. Bureau of Labor Statistics. (1988b). Educational attainment of workers: March 1988, Unpublished internal document.

U.S. Bureau of Labor Statistics. (1989a). Employment and Earnings, 36(1), 181.

U.S. Bureau of Labor Statistics. (1989b). Employment and Earnings, 36(4), 72.

U.S. Bureau of Labor Statistics. (1990). Employment and Earnings, 37(1), 181, 240.

U.S. Bureau of Labor Statistics. (1991). Employment and Earnings, 38(4), 29.

\section{Authors}

JOHN H. BISHOP, Associate Professor, Center for Advanced Human Resource Studies, Cornell University, 393 Ives Hall, Ithaca, New York 14853. Specialization: economics.

SHANI CARTER, Graduate Student, School of Industrial and Labor Relations, Cornell University, 158 Ives Hall, Ithaca, New York 14853. Specializations: human resources and labor economics in industrial and labor relations. 